\title{
The Roles of Bunga Selasih Foundation as Social Learning Idea for The Elderly
}

\author{
Ahmad Yasar Ramdan ${ }^{1 *}$, Yoyon Suryono ${ }^{2}$, Jubaidah Hasibuan ${ }^{3}$ \\ ${ }^{1,2)}$ Graduate School, Universitas Negeri Yogyakarta \\ ${ }^{3)}$ Education Faculty, Universitas Negeri Medan \\ *ahmadyasar.2018@student.uny.ac.id
}

\begin{abstract}
This study aimed to reveal: 1) Roles of Bunga Selasih Foundation as idea of social education, 2) Social education services program for the elderly, 3) Supporting and inhibiting factors for the implementation of social education. This was descriptive research by implementing qualitative approach, while the data were collected through interview, observation, and Focus Group Discussion. The informants of this study were leaders, administrators, and members. Interactive analysis was used in this study. The results showed that the roles of Bunga Selasih foundation was: 1) facilitator, facilitating members in the care of Islamic corpses, 2) patron, providing services to protect the rights of members, 3) motivators, enhancing spirit of life and self-awareness for the elderly by facilitating Islamic boarding schools husnul khotimah, and majelis taklim. The supporting factor in conducting the program is the complete facilities, while the inhibiting factor was the members are still not actively involved in the program.
\end{abstract}

Keywords: roles of bunga selasih foundation, social education, the elderly

\section{Introduction}

Old age refers to the last stage of humans' life cycle, where in this stage, a person will experience a lot of setbacks, such as physical and psychological functions. World Health Organization (WHO) has classified old age into four, such as young-old (45-59 years old), middle-old (60-74 years old), very old (75-90 years old), and oldest-old (>90 years old) [4].

Based on the data of population census conducted by Central Statistics Agency, in 2006 the number of the elderly in Indonesia reached 19 million with a life expectancy of 66.2 years. In 2010, it was predicted that the number of elderly people was 23.9 million $(9.77 \%)$ with a life expectancy of 67.4 years. Meanwhile, according to the Coordinating Minister for Public Welfare (Menkokesra), in 2020 the number of elderly is predicted to be 28.8 million (11.34\%) with a life expectancy of 71.1 years [2]. The increase on life expectancy in Indonesia is one indicator of successing Indonesia's development, so this condition will increase the rate of aging [9].

The increase in life expectancy and elderly population indicates the success of a country, but on the other hand it also gives new challenges for government and society. The number of elderly people that increases rapidly will change the structure of the population into aging population. On the other words, the elderly have decreased, physically, socially, cognitively and economically [6]. 
The increase of life expectancy means that individuals can live longer or enjoy their longer life. Thus, this will increase the number of elderly people. This situation will certainly have a significant impact, such as causing economic and health problems in the elderly [19]. In order to prevent more biggest problems, several anticipatory efforts should be conducted in order to make elderly people be physically and mentally healthy [16].

Meanwhile, when people entering the old age, they begin obtaining multiple pathological physical conditions (for example their energy has decreased, their skin turn out to be wrinkles, some of their teeth has fallen out and loose, their bones have been brittle, etc. Generally, their physical conditions will be decreased more when they have entered the old age. This can cause a disruption or abnormality on their physical, psychological, and social functions, which make them become more dependent on the others [8].

As people getting older, they do not only think about life after death, but also about the death itself, which is almost close to them. They can be fearful since they are not ready to face it [21]. Therefore, in enhancing the eldery, a cross-sector collaboration is necessary, such as contributions from non-governmental organizations to actively participate in paying more attentions and provide several treatments for the elderly [15].

People's anxiety about death can be caused by death itself and what will happen after death, such as leaving their friends and family, or thinking that the place that they will be visited after death is very bad [1]. Such anxieties in facing death will make the elderly lack of preparations. Readiness is defined as a condition when someone is totally ready to face a situation [20]. The elderly's readiness in facing the death can be influenced by several aspects, such as psychological, social, physical, and spiritual aspects [11].

Bunga Selasih Foundation is a social institution which aims to educate and guide elderly people about the ways to take care of corpse, based on Islamic guidance. This foundation was established on April $1^{\text {st }}$, 1998. The existence of Bunga Selasih Foundation is to provide the needs of the Muslims by giving experience and knowledge to the elderly in preparing death. Since everyone will face death, it must be prepared as early as possible, starting from our own readiness and the management of the corpse.

When the foundation was build, several problems certainly happened and could not be avoided, like in the management of the corpse. We cannot avoid the reality that when we concern with the rules, procedures, speech, and cultures that are implemented by the people (for example from the preparation to burying the body), the ways are not based on Islamic guidance and not perfectly Syariah. Thus, it is such a violation in Islam, like violating the purity of Tauhid. The treatments of the corpse, which start from the preparation, bathing, dressing with a shroud, taking a pray, and burial process, should be based on Islamic guidance as fardhu kifayah. Taking care of corpse is all Muslim's responsibility, not only the rois or ulema. Hence, every Muslim should be able to conduct it based on Islamic and medical guidance.

Therefore, regarding to the development and society's needs to manage those activities and equipments, the office was build in Yogyakarta, next to Dr. Sardjito. The services provided by this foundation have also developed into institutions that are dedicated to social education, especially for the elderly. At this age, their spiritual conditions must be enhanced by conducting several programs that can help them to accept everything that happens to them. Hence, religious education is necessary to avoid such mental and spiritual disorders [17].

Based on preliminary observations on Monday, April $29^{\text {th }}, 2019$, the number of members in the foundation was 8.200 active members, and the majority are elderly. Therefore, the religious guidance is one of the priorities for elderly members, such as conducting majelis taklim, the guidance for treating corpse, and facilitating a special boarding school for the 
elderly. Through those programs, hopefully it will bring the elderly closer to God and increase the social interaction among members. The results of previous research by Fitriyadewi \& Suarya's, higher social interaction conducted by the elderly could increase their life satisfaction [5], since everyone has self-beliefs which control themselves to handle their thoughts, feelings, and actions [25].

Based on the descriptions of the problem, Bunga Selasih Foundation is expected to provide a new way in providing education for the elderly, since the increasing of humans' life expectancy give a new approach in providing the best servants for the community, in order to fulfill their needs. Therefore, the elderly still feel happy, especially when acquiring the knowledge, and they can live their old life better.

\section{Research Method}

This study implemented a qualitative approach, while the data consisted of oral or written sentences rather than numbers. The research was located at Bunga Selasih Foundation Yogyakarta. The data were collected through interviews, observations, and Focus Group Discussion (FGD). Purposive sampling was implemented in order to select the chairperson, management, and elderly members. Source triangulation was used as the trustworthiness of the data. Data analysis techniques used in this study were adopted from Miles and Huberman's interactive data analysis, consisted of data collection, data reduction, data presentation, and drawing conclusion (verification) [13].

\section{Results and Discussion}

The development of Bunga Selasih Foundation in providing social services has developed rapidly in overcoming problems that occur in the community. This foundation used to focus only on services of how to take care of corpses based on Islamic guidance, starting from a strong emphasis on the separation of men and women's bodies, until how to use camphor powder, sandalwood powder, and the shrouds. The processess to take care of the corpse is no longer based on the community, but now it is conducted by the professionals. Then, Bunga Selasih Foundation enhances their benefits to society, especially in social education for the elderly.

Bunga Selasih Foundation is very helpful for the elderly in improving and enhancing their abilities in social functions and creating conditions that enable them to be able to learn and have awareness for the importance of preparing themselves in the face of death. Naftali et al explained that when the elderly are given the concept of religion and divinity, there is a sense of gratitude for what is predestined by God, giving rise to a sense of calm and being within themselves [14]. As explained in the results of the study, the role of the Bunga Selasih Yogyakarta Foundation is to provide education to the elderly in improving the quality of life of the elderly so that the beneficiaries can carry out their lives appropriately and increase their capacity to be able to contribute or take part in the process of organizing corpses. So, in an effort to develop the quality of human resources, education is the right solution in realizing this [12].

The role of social education for the community has significantly improved the quality of the elderly. The Foundation conducts progressive development in order to provide benefits to people to follow Islamic guidances. The benefits of the program are explained by Rahmawati \& Kisworo as one of the supporting factors in social services or community, by conducting active participations in each meeting [18]. 


\section{The Roles of Bunga Selasih Foundation as Social Education for The Elderly}

1) Facilitator

As the facilitator, Bunga Selasih Foundation plays a role in raising people's awareness and providing support to the elderly. By enhancing awareness from either the elderly or the community, they can give contribution in helping the elderly to solve various problems as they are getting older [21]. The foundation facilitates the elderly by educating them with various guidances and counseling programs, such as treating corpses based on Islamic and medical Syariah, providing transportation (ambulances), and providing special burial places for Muslims. In addition, it also provides spiritual guidance services such as majelis taklim, which fulfills the elderly's needs, either in this world or the hereafter. In the process of mentoring the elderly, the foundation provides several facilities such as prayer equipment, religious books, and Al- Qur'an, in order to enhance their awareness that humans are God's creations, and to Him we will return.

2) Protector

The active members of this foundation consist of several groups, such as farmers, traders, teachers, and lecturers, and all of them have the same rights without any specific restrictions. However, the foundation implements a policy to divide the rights of members into two groups, such as the rights for members who have been registered for 3 years and who have not yet reached three years, especially in learning how to take care of corpses.

a. For the members who have been registered for 3 years or more:

- The foundation will take care of them until the funeral processess, such as bathing, dressing with a shroud, praying, and burying.

- The foundation facilitates transportation (ambulance) and spiritual services from their home to the funeral, if there is no charge in the DIY area.

- Taking care of the corpse eventhough it is out of Yogyakarta, with a predetermined fee.

b. For the members who have not been registered for three years, there are additional fees for the funeral and the transportation.

The fee that the members spend for each month is Rp. 10.000 per member, by using a cross-subsidy system. The cost of taking care of the corpses, from bathing to funeral is Rp. $1.000 .000 /$ corpse, but with cross-subsidy systems, the cost can be divided with other members.

3) Motivator

The foundation provides guidance and education programs which are consisted of several stages: (a) initial approach stage; (b) the stage of deepening problem; (c) intervention; (d) the stage of implementing spiritual / religious guidance services; and (e) evaluation and termination stage, as the effort to overcome the elderly's stress when they feel anxious about their current condition, and they fearful with how to deal with the life after death. An effort that can encourage someones to deal with the problems is to give motivation, since by giving motivation, people are easier to deal with their problems [10].Therefore, spiritual guidance is provided by conducting majelis taklim and discussions, in order to motivate them to be close to God, in order to feel safe, secure, and reduce their psychological anxieties. The foundation is managed by several management, such as the board of trustees, supervisor, coordinators, and representatives. The sources of funds are 
obtained from: (1) Registration fees, (2) Membership fees, (3) Infaq / shodaqoh, (4) Halal businesses, and (5) Additional helps from the donors and local governments. By providing a good and professional management system, it supports the services for members, especially in improving the social welfare of the elderly.

\section{The Educational Services Programs for The Elderly}

1) Conducting guidance and counseling about how to take care of the corpse based on Islamic and medical sharia

Guidance and counseling on how to take care of the corpse aims to provide the members' skills. At the present, the guidance and counseling were dedicated to a wider community, especially Islamic Universities in Yogyakarta, since this knowledge is very necessary in the future. In this counseling process, it is possible to share knowledge with individuals or groups in order to answer the problems which currently discussed in the community. This interaction requires awareness in order to answer various problems in the community and enhance the adaptation process [3].

2) Providing an elderly Islamic boarding school: Husnul Khotimah

The boarding school is a place where the elderly can fill their old days with worships in order to close with Allah SWT, with the hope of getting happiness in the world and the hereafter, and husnul khotimah [10]. Husnul Khotimah Islamic boarding school is dedicated to elderly members by teaching how to read Al-Qur'an, implementing appropriate prayer procedures, and studying Islamic sharia. These knowledges are needed by the elderly in order to spend their time with useful activities and live a better life.

3) Conducting a Majelis Taklim

In providing spiritual or religious guidances services, Bunga Selasih Foundation conducts the lectures through dialogue or discussion, in order to create peaceful and calm atmosphere. The additional insight into religious knowledge is an important factor in strengthening faith and spiritual health. In this case, Bunga Selasih Foundation helps the elderly to remind and getting closer to Allah SWT by continuing to learn and increase their knowledge about religion, since learning is the process of constructing knowledge from experience for a better present and future life [24]. By fulfilling their spiritual needs, it helps the members' to clear their mind from the bad things. By spending their time with useful activities, they can interact with the seniors, in order to enhance the awareness that they have a social obligation to help each other as human beings. The elderly's life satisfaction is found in social relationships and social support [7]. They feel lovable, safe, and comfortable, and it makes their life better. In addition, social services to the elderly are important aspects which are handled through various activities, based on their duties and functions [23].

\section{Supporting and Inhibiting Fators in Conducting The Social Education}

In conducting guidance and counseling activities as the efforts to provide education for the elderly in Bunga Selsih Foundation, they are influenced by several factors, such as supporting factors and inhibiting factors. Supporting factors in the implementation of guidance services for elderly are adequate facilities or infrastructure in the institution itself, as the collaboration between Bunga Selasih Foundation and several regional agencies, such as the government, Dr. Sarjito, Panti Rapih Hospital, Indonesian Islamic University, Sunan Kalijaga Islamic University, BPBD DIY, and the community who have provided effective and efficient work in supporting the services and counseling to the community, especially the elderly. The 
elderly's spiritual or religious needs have been well provided by Bunga Selasih Foundation. Although the members should pay fees, but for them it is not that much, if it is compared with the facilities and programs provided by this Islamic institution.

However, there are also some inhibiting factors in conducting guidance and counseling services, such as the limited number of employees or human resources at Bunga Selasih Foundation, which are not balance with the total number of the members in the foundation, which consists of 8,200 active members. This makes the employees feel inadequate, especially in handling the corpse management services. Sometimes, in one day, there are 3 to 8 corpses that must be taken care of. With the limited number of human resources, the service will not be optimal since the family members have to wait. Hence, this problem sometimes makes the family of the members give complaints to the institution. In addition, the implementation of spiritual or religious guidance did not run well even though it had been scheduled. This is because the members are unable to come, since they do not have much time and limited mobilization when no one can take them to the institution. The religious service program was only attended by a few members who were close to Bunga Selasih Foundation.

\section{Conclusion}

Based on the results of the research, it can be concluded that the roles of Bunga Selasih Foundation as an idea of social education are: 1) Facilitator, with various guidances, education, and counseling program services; 2) Protector, when all of the members have the same rights without certain restrictions; 3) Motivator, as an effort to overcome the elderly's with spiritual guidance in order to motivate them with knowledge and improve their social welfare. Efforts to implement the elderly's social education are: 1) Organizing guidance and counseling about Islamic and medical shari'a, especially for taking care of corpse; 2) Providing Husnul Khatimah Islamic boarding school for the elderly; and 3) Conducting Majelis Taklim assemblies. The supporting factors for the implementation of the guidance and education service program for the elderly are: the programs are implemented well to solve the problems faced by the elderly, as well as all the elderly's needs, especially for their spiritual needs, which have been managed professionally. Meanwhile, the inhibiting factor is the limited number of employees or human resources at Bunga Selasih Foundation, compared to the number of active members, and the implementation of spiritual or religious guidance is not running well even though it had been scheduled. This happens since the members have limited time and limited mobilization to come to Bunga Selasih Foundation.

Therefore, this research aimed to describe the roles of one of the social institutions that provided awareness in providing knowledge to the elderly, especially spiritual, emotional, and social knowledge. However, the problems faced by the elderly are diverse and complex. Therefore, hopefully other researches can be interested in examining the role of all parties, especially the elderly's family, which can give contribution in supporting the elderly. Besides that, they can be more productive by conducting positive activities to improve their social welfare.

\section{References}

[1] Alimul Hidayat, A. Azis. (2006). Pengantar Kebutuhan Dasar Manusia: Aplikasi Konsep dan Proses Keperawatan. Jakarta: Salemba Medika.

[2] Efendi, F. \& M. (2009). Keperawatan kesehatan komunitas : Teori dan praktik dalam keperawatan. Jakarta: Salemba Medika. 
[3] Eraut, M. (2007). Learning from other people in the workplace. Oxford Review of Education, 33(4), 403-422. https://doi.org/10.1080/03054980701425706

[4] Fatmah. (2010). Gizi Usia Lanjut. Erlangga : Jakarta

[5] Fitriyadewi, L. P. W., \& Suarya, L. M. K. S. (2016). Peran Interaksi Sosial Terhadap Kepuasan Hidup Lanjut Usia. Jurnal Psikologi Udayana, 3(2), 332-341.

[6] Indrawati, \& Raharjo, T. J. (2014). Peranan Pekerja Sosial dalam Meningkatkan Kesejahteraan Sosial Lanjut Usia (Lansia) di Unit Rehabilitasi Sosial Purbo Yuwono Brebes. Journal of Non Formal Education and Community Empowerment, 3(1), 61-67.

[7] Jin, Q., Pearce, P., \& Hu, H. (2017). The Study on the Satisfaction of the Elderly People Living with Their Children. Social Indicators Research. https://doi.org/10.1007/s11205017-1803-1

[8] Kartinah, \& Sudaryanto, A. (2008). Masalah Psikososial pada Lanjut Usia. Berita Ilmu Keperawatan, 1(1), 93-96.

[9] Kholifah, S. N. (2016). Modul Keperawatan Gerontik. Jakarta Selatan: Kementrian Kesehatan RI.

[10] Khotimah, H. (2014). Peran Pesantren Lansia bagi Perkembangan Pendidikan Islam: Studi Kasus di Pondok Pesantren Raudlatul Ulum Kencong Kepung Kediri. Didaktika Religia, 2(2), 1-24.

[11] Meiner, Sue E., dan Annette G. Lueckenotte. (2006). Gerontologic Nursing (3th ed.). Philadelphia: Mosby Elsevier.

[12] Miradj, S., \& Sumarno. (2014). Pemberdayaan Masyarakat Miskin, Melalui Proses Pendidikan Nonformal, Upaya Meningkatkan Kesejahteraan Sosial di Kabupaten Halmahera Barat. Pendidikan dan Pemberdayaan Masyarakat, 1(2), 101-112.

[13] Miles, Mattew \& Huberman, Michael. (2014). Analisis Data Kualitatif. Jakarta: Universitas Indonesia.

[14] Naftali, A. R., Ranimpi, Y. Y., \& Anwar, M. A. (2017). Kesehatan Spiritual dan Kesiapan Lansia dalam Menghadapi Kematian. Buletin Psikologi, 25(2), 124-135. https://doi.org/10.22146/buletinpsikologi.28992

[15] Pertiwi, H. W. (2013). Faktor-Faktor yang Berpengaruh dengan Frekuensi Kehadiran Lanjut Usia di Posyandu Lansia. Bidan Prada: Jurnal Ilmu Kebidanan, 4(1), 1. 